\title{
CIVIL SERVICE LAW
}

\section{CHAPTER 1 \\ GENERAL PROVISIONS}

\section{Basis:}

Article 1

In accordance with Article 50 of the Afghanistan Constitution, this Law has been enacted to establish sound administration, to implement reforms in the administrative system, and to regulate the activities of the Civil Service.

\section{Objectives:}

\section{Article 2}

This Law has the following objectives:

1. To establish sound administration through the planning and implementation of reform of the country's administrative system.

2. To determine the duties of Civil Service.

3. To fill Civil Service posts on merit and competency.

4. To regulate personnel management arrangements and duties of civil servants.

\section{Civil Service:}

\section{Article 3}

The Civil Service performs all the executive and administrative activities of the Government based on provisions in law.

The Civil Service includes the following activities:

1. Manages, regulates and delivers government services.

2. Develops policies, and provides and offers professional advice.

3. Develops, prepares and implement laws, decrees and relevant regulations

\section{Civil Servant:}

\section{Article 4}

1) A civil servant is a person appointed by the Government to perform its executive and administrative duties based on the provisions in law. The ranks and grades of civil servants will be regulated according to the relevant legal document.

2) Any person who is not included in the ranks and grades described in Clause 1 of this Article is not considered to be a civil servant. 


\section{Chapter 2 \\ Independent Administrative Reform and Civil Service Commission (IARCSC)}

\section{Leadership of IARCSC:}

\section{Article 5:}

1) The IARCSC is established in order to lead, regulate, reform, formulate and implement structure policies of public administration system.

2) The IARCSC is hereafter referred to in this Law as the Commission.

3) The Commission consists of nine members appointed by the President for a period of three years. Their reselection is made at discretion of the President.

4) The Commission is managed by a Chairman appointed by the President.

5) The Chairman leads the Independent Administrative Reform and Civil Service Commission, monitors the affairs of the Boards and presents the report of the performance to the President's Office. (President and 2 Vice Presidents)

6) The Chairman of the Commission assigns five members to the Civil Service Appointments Board and three members to the Civil Service Appeals Board.

\section{Structure:}

\section{Article 6:}

The Commission consists of:

1) The Civil Service Management Department

2) The Civil Service Appointments Board

3) The Civil Service Appeals board

4) The Administrative Reform Secretariat

\section{Independence:}

\section{Article 7:}

1) The Commission is independent in its performance and is directly responsible to the President's Office. (President and Vice Presidents)

2) The Civil Service Appointments and Appeals Boards are independent in their performances; they present their reports to the President through the Chairman of the Commission.

3) The Chairman of the Commission does not participate in their decision making.

\section{Attributes of Commission Members:}

\section{Article 8}

The person who has the following requirements can be appointed as a Member of the commission:

1) Afghan nationality

2) At least 30 years of age

3) High education and adequate experience

4) Good reputation and behaviuor

5) No criminal convictions and no crimes against humanity 


\section{Article 9}

The Members of the Commission cannot use their authority for language, regional, tribal, religious and party reasons whilst a Member of the Commission

\section{Deposing a Member of the Commission}

\section{Article 10}

A member of the Commission can be dismissed by the President for the following reasons:

1) Failure to perform duties

2) Misuse of authority

3) Conviction of a criminal offence or crimes against humanity whilst a member of the Commission

\section{Chapter 3 \\ Civil Service Management}

\section{Objective:}

Article 11

1. The Civil Service Management Department develops policies relating to the structure, management and appointment of civil servants, and monitors their implementation in accordance with the provisions of this Law and other legal documents.

2. The Civil Service Management Department consists of professional and administrative offices that perform their duties in accordance with the relevant legal documents.

\section{Duties and Authorities:}

\section{Article 12}

The Civil Service Management Department has the following duties and authority:

1) To develop and monitor policies relating to appointment and employment; hours of work, salaries, privileges, attendance, leave, promotion, retirement and other personnel matters related to the civil servants and their implementation through the relevant agencies within the provisions of law

2) To monitor the management and formulation of civil servants' performances in accordance with the relevant legal documents.

3) To obtain necessary documents from Ministries and Government Agencies

4) To monitor the implementation of policy relating to work safety environment and insurance for civil servants

5) To prevent racial, tribal, language, religious, sexual and political discrimination, and to take account of sexual and tribal balance in the Civil Service.

6) To develop and implement a strategy for the management and administration of civil servants' training and the development of their skills. 
7) To observe the provisions of enacted laws, regulations and international conventions, and to use internationally accepted principles and experience, in relation to the Civil Service.

8) To assist and advise Ministries and Government Agencies and their relevant unions on all matters relevant to the Civil Service.

9) Put in place procedures in order to test, train, develop and appraise the performances of the civil servants.

10) To develop regulations; approve procedures in order to implement policies and guide the Ministries and Government Agencies for effective implementation of the provisions of this Law.

11) To report on performance to the President through the Chairman of the Commission.

\section{Chapter Four \\ Civil Service Appointments Board}

\section{Structure:}

\section{Article 13}

1) The Civil Service Appointments Board based on Clause 6 of Article 5 consists of five Members

The Members of the Board can elect one of their number as Chairman for a period of one year.

2) If the workload becomes heavy, the President may appoint five temporary members for a period of six months.

3) The Members of the Board cannot work in other government or nongovernmental agencies whilst remaining Members of the Board.

\section{Duties:}

\section{Article 14}

The Civil Service Appointments Board has the following duties and authority:

1) To identify and recommend the recruitment, appointment, promotion, transfer, retirements, pension payment and other personal matters of high-ranking civil servants for the approval of the President.

2) To require Ministries and Government Agencies to provide information about vacant posts

3) To approve job criteria and advertisements; and to determine short-listing and final selection of the candidates

4) To chair short-listing and final selection panels;

5) To recommend selected candidates to the President for approval;

6) To demand written records from Ministries and Government Agencies in accordance with the relevant legal document.

7) To monitor appointments in Ministries and Government Agencies, based on the relevant legal documents.

8) To report violations in accordance with this Law and the relevant legal document. 


\section{Process of Appointment:}

\section{Article 15}

1. The appointment of civil servants is made through open competition under the following conditions:

1. Civil Service vacancies are advertised to attract suitable candidates. The application forms of the candidates are reviewed by the Appointment Board and the representative of the relevant Ministry of Agency for short listing and the candidates who have been short-listed are interviewed.

2. The identification and selection of the best candidate who meets the requirements of the post.

The vacant post has a job description that includes objectives, main duties and requirements about abilities, experience and skills of the candidates.

2. Final Selection Panel consists of two members from the Appointment Board and the authorised representative from the relevant Ministry or Government Agency.

3. Short-listing and interviewing for final selection is carried out fairly without any discrimination, considering the background and is based on pre-determined job criteria. The selected candidate is recommended for appointment after final interview.

4. Relevant documents shall be kept for a period of 3 years.

\section{Appointment Board Secretariat:}

\section{Article 16}

The Civil Service Appointment Board contains a Secretariat whose functions will be regulated in accordance with the relevant procedure.

\section{Chapter 5 \\ Civil Service Appeals Board}

\section{Structure:}

Article 17

1- The Civil Service Appeals Board based on Clause 6 of Article 5 consists of three Members.

The Members of the Board can elect one of their number as Chairman for a period of one year.

2- The Members of the Appeals Board cannot work in other government or nongovernmental agencies whilst remaining Members of the Board.

\section{Duties and Authorities:}

\section{Article 18}

The Civil Service Appeals Board has the following duties and authorities:

1. To hear appeals from civil servants who consider they have been disciplined unfairly;

2. To hear appeals of unlawful instructions and orders. 
3. To hear appeals of violations happened against the regulation of employees' code of conduct.

4. To hear appeals of employees who are denied access to their personal files

5. To hear appeals of employees resulting from not receiving applications without any reliable reasons.

6. To hear appeals from civil servants and other applicants for Civil Service posts who consider they have been discriminated against or treated unfairly by the Civil Service Appointments Board or the appointments panel of the relevant Ministry or Government Agency during the recruitment process

7. To decide on appeals resulting from discriminatory and unfair appointment.

8. To hear any other appeals that are considered to be evaluated by the board;

9. To report on annual performance to the President through the Chairman of the Commission.

\section{Process of Performances:}

\section{Article 19}

1. While receiving appeals from employees, the following actions shall be taken:

1) To hear appeals presented to relevant ministry or agency by the employee, but are not heard.

2) Appeals must be submitted in writing, together with any supporting documentation. The appeals that do not have documentary proofs are rejected by the Board and written reasons for rejection are presented to the appellant.

2. The Appeals Board can demand the needed documents and other evidence either from the appellant or the Government organisation concerned in order to prove the matter.

3. If required, the Board can take oral evidence from the appellant, witnesses and its own specialists.

4. If required, the Appeals Board can seek advice from external expert witnesses.

5. The Appeals Board can establish separate procedures for better consideration of appeals.

6. Ministries and Government Agencies must implement the decisions and requirements of the Appeals Board in accordance with the provisions of this Law.

7. The Appeals Board's decisions are recorded and formally notified to the appellant and the relevant Ministry or Government Agency.

8. If one of the parties disagrees with a decision of the Appeals Board, he/she can process his/her appeal with the relevant Court of Law.

\section{Board Secretariat:}

\section{Article 20}

The Civil Service Appeals Board contains a Secretariat whose functions will be regulated in accordance with the relevant procedure. 


\section{Chapter 6 \\ Administrative Reform Secretariat}

\section{Duties of Secretariat:}

\section{Article 21}

1. The Administrative Reform Secretariat undertakes activities concerning executive, financial and administrative matters under the authority of the Chairman in accordance with the relevant procedure.

2. The Administrative Reform Secretariat monitors the implementation of administrative reform programmes, projects and activities, and reports to the Chairman of the Commission.

\section{Chapter 7 \\ Civil Servants}

\section{Civil Servants' Positions}

\section{Article 22}

Civil service positions are classified by reference to ranks, grades, steps, level of responsibilities, authorities and nature of the job in accordance with the relevant legal documents.

\section{Appointment of Civil Servants:}

\section{Article 23}

Civil Servants are appointed based on merit and professional skills without any kind of discrimination in accordance with the relevant legal documents.

\section{Personnel Management:}

\section{Article 24}

The personnel management of civil servants will be regulated in accordance with the provisions of this Law, Labour Law and other relevant legislative documents.

\section{Duties and Responsibilities:}

\section{Article 25}

Civil servants have the following duties and responsibilities:

1. To perform their daily duties in accordance with the employment contract and any other job agreements.

2. To serve the Government loyally, impartially and honestly, observing the administrative chain of command.

3. To provide practical advice to the organisation.

4. To preserve job confidentialities.

5. To uphold the authority and reputation of the employment and organisation. 
6. To behave appropriately towards clients and co-workers.

7. To take every responsibility to provide good public service

8. To observe and implement laws and regulations impartially and consistently.

9. To follow up training and professional development programmes provided by the organization.

10. To avoid misusing data and opportunities provided in the work place for personal gain or the benefit of others.

11. To protect public property and funds.

12. To avoid insouciance and improvidence in the workplace.

13. To avoid taking any actions that might have an adverse effect on Government policies in relation to the Civil Service.

\section{Prohibition of Other Employment:}

\section{Article 26}

Civil servants cannot undertake other employment in official time.

\section{Rights and Privileges:}

\section{Article 27}

Civil servants have the following rights and privileges:

1. Promotion, salary and benefits based on the relevant legal documents

2. A pension according to the relevant legal document.

3. Enhancement of knowledge and professional experience through training programmes and other facilities.

4. A safe working environment, insurance cover, and indemnification against loss whilst performing official duties.

5. Protection of human values; providing safety from all physical, ethic and psychological harassment; observance freedom, and avoidance of any kind of discrimination and favoritism i.e. sexual, ethnical, tribal, religious, political, appearance and civil status.

6. Freedom to express views on the legality of orders issued by a senior authority.

If the employee considers that the order is illegal or contrary to regulations, he / she should report the matter in writing to his / her manager. If the order is confirmed in writing, any repercussions are the responsibility of the manager and not the employee.

7. The right of appeal against illegal and unfair decisions in the workplace.

8. Resignation from the job in accordance with the relevant legal document.

9. Voluntary participation in associations and gatherings established to protect and improve the position of civil servants in accordance with provisions in law. 


\section{Chapter 8 \\ Miscellaneous Provisions}

\section{Budget of the Commission}

Article 29

The Commission is an independent budgetary unit whose budget is processed in accordance with provisions in law.

\section{Discipline of Civil Servant:}

\section{Article 30}

A civil servant who does not perform his day to day duties in accordance with the relevant legal documents will be disciplined.

\section{Enactment:}

\section{Article 30}

This Law enters into force from the day it is signed and shall be published in the Official Gazette. With enactment of this law, decree \# 257 dated 2/3/1381 SY, decree \# 25 dated 20/3/1382 SY, decree \# 33 dated 21/4/1382 SY and the Regulation on Procedure and Functions of Independent Administrative Reform and Civil Service Commission published in Official Gazette \# 810 dated 30/5/1382 SY, along with the attachments and other contradictory provisions to this law shall be cancelled. 